\title{
Study the Different Properties of Innovative Cake Blends for Patients with Gluten Sensitivity
}

\author{
Dina H.EL Bushuty* and Naglaa M.Shanshan* \\ *Home Economics Dept., Fac. Specific Education, Damietta Univ., Egypt.
}

\section{Introduction}

Number of patients with celiac disease were increased in recent years (Catassi et al., 2008). Celiac disease is described by a strong immune response to specific amino acid sequences found in the prolamin bits of wheat, barley and rye. When people with celiac disease have foods containing gluten, their immune system responds by breaking down the intestinal villi leading to the mal absorption of nutrients, so adversely affecting all systems of the body (Hill et al., 2005). Whereas, the happening of this disease has been traditionally despised. Nowadays, an occurrence in the range of 1 patient per 130-200 people is known in developed countries (Sollid, 2002 and Fasano et al., 2003). Celiac disease remains a difficult case due to the steady increase in knowledge dealing with pathophysiology, diagnosis and possible treatment options (Caio et al., 2019). The main reasons of celiac disease are the change in people's eating habits and excess in use of fast foods. Consequently, there is an increasing demand for gluten-free high quality products. Therefore, this call cereal technologists to a defy, concerning the low-baking quality of the glutenfree flour resulted from absence of gluten (Arendt et al.,2008).However, patients showing nutritional deficiencies could demand supplementation of their food with vitamins, antioxidants, minerals, and proteins to correct deficiencies and return nutrient reserves (Osella et al.,2014 and Bascujonn et al.,2016). It was found that celiac disease patients suffers from the shortage of gluten free products with the after negative effects on nutritional and health status (Bourekoua et al., 2016). Beside this , absence of gluten often makes rather liquid dough and may lead to bakery products with low volume, weak color, dense shape, and other quality defect (Catassi et al., 2008).

Corn flour is among the best ingredients in the preparation of glutenfree products .Corn starch was used separately in preparing bread used by celiac people in food preparation. Even though corn flour supplies many micro- and macronutrients, amounts of some main nutrients are deficient. Therefore, consumption of these products contributes only small amounts of proteins, minerals and dietary fibers, consequently increasing the danger of nutritional shortage associated with celiac Disease ( Mastromatteo et al., 2011 and Schober et al., 2008). In current times, the attention has been concentrated on new application of legume flour or ingredients. The concern in this crop category is mainly due to their functional characteristics, like solubility and water-binding capacity, which play an essential role in gluten-free food 
formulation and treatment. Their nutritional profile may also counteract the shortage of nutrients commonly highlighted in commercial gluten-free bakery and pasta products giving valuable sources of protein, dietary fiber, vitamins, minerals, and complex carbohydrates, which in turn have a positive impact on human health ( Foschia et al., 2017). Legume flours including fava beans, garbanzo beans, soybeans and chickpeas which good origin of protein and fiber best used in blends with other gluten-free flours to balance taste and texture (Stone et al., 2017). Soybean could be an fundamental part of functional foods, as well as it could be used for raising of product quality. Soybean also contains up to $45 \%$ protein and as a good source of vitamins and mineral supplies sufficient amount of different amino acids required for repairing the destroyed body tissues (Ahmad et al., 2014 and Islam et al., 2007). Chickpea (Cicer arietinum) is significant source of protein, carbohydrate and minerals, especially to the population groups of developing nations. Chickpea contains $21.1 \mathrm{~g}$ protein, $3.1 \mathrm{~g}$ fat, $53.4 \mathrm{~g}$ carbohydrate, $11.1 \mathrm{~g}$ fiber and $5.9 \mathrm{~g}$ ash, $360 \mathrm{mg} \mathrm{Ca}, 315 \mathrm{mg} \mathrm{P}, 8.2 \mathrm{mg} \mathrm{Fe}, 5.4 \mathrm{mg} \mathrm{Zn,} 5.4 \mathrm{mg} \mathrm{Mn}, 1.1$ $\mathrm{mg} \mathrm{Cu}$ per $100 \mathrm{~g}$ (Dimitrios et al., 2006 and Khan et al., 2010).

Presence of high protein content in chickpea is convenient for patients with celiac disease. Furthermore, as proteins can make a network such as gluten, chickpea which could improve gas retention, volume and bread quality in general (Miñarro et al., 2012).

Lupine (Lupinus albus spp) as a valuable old legume contains comparatively higher amount of protein than cereals and other legumes except soy. Lysine content of lupine proteins is high while methionine content is low. Lupine is also rich in dietary fiber (30-40\%), fat (6-13\%), phytochemicals involving antioxidants and phytosterols, vitamin and minerals (Faluyi et al., 2000).

Cake is one of the most favourite bakery products, consumed worldwide by all ages in large quantities. The quality of cakes relies on many factors, such as the ingredients used for batter preparation, aeration of batter and process conditions. A number of studies are on the formulation of gluten-free baked cakes (Gularte et al., 2012 and Matos et al., 2014). Beside this , Cake is considered one of the most significant bakery products for Egyptian people it is either home-made or produced on trade scale( Doweidar, 2006).

The aim of the present study is to investigate the effect of partial substitution of corn flour by soy flour (SF ), chickpea flour ( $\mathrm{Cp} \mathrm{F}$ ) and lupine flour (LF) at levels $15 \%$ and $30 \%$, on chemical, physical, texture ,color and sensory characteristics of innovative gluten-free cakes.

\section{Materials and Methods}

\section{Materials}

Yellow corn flour (97\% extraction) was obtained from Egyptian Company for corn products $10^{\text {th }}$ of Ramadan City, Egypt. Corn Starch, sugar, 
eggs, butter, yogurt, baking powder and vanilla were obtained from a local market in Damietta Governorate, Egypt. Soy beans, chick peas and sweet lupine were obtained from a local market in Damietta governorate, Egypt.

\section{Methods}

Soy beans, chickpeas and sweet lupine were prepared for milling according to (Al-Omari,2009) method. Soy beans, chick peas and sweet lupine were cleaned (discarding small broken, moldy and damaged beans), then washed using distilled water and then sterilized with $0.3 \%$ sodium hypochlorite solution for $1 \mathrm{~min}$, after that rewashed more one time with distilled water, then soaked in distilled water for $20 \mathrm{~h}$ and lastly dried in a ventilated oven (Vindon, England) at $55^{\circ} \mathrm{C}$ for $18 \mathrm{~h}$. After that, they were ground by an electrical mill (Braun, Germany) to pass through a 60 mesh sieve (British standard screen). The milled flours were stored in air-tight polyethylene bags at $4^{\circ} \mathrm{C}$ till required.

\section{Preparing of gluten free cake samples}

Seven gluten -free cake flour blends were prepared : control: $100 \%$ corn flour (CF), $85 \%$ corn flour and 15\% chickpea flour $\left(\mathrm{Cp}_{1} \mathrm{~F}\right), 70 \%$ corn flour and $30 \%$ chickpea flour $\left(\mathrm{Cp}_{2} \mathrm{~F}\right), 85 \%$ corn flour and $15 \%$ soy flour $\left(\mathrm{S}_{1} \mathrm{~F}\right), 70 \%$ corn flour and $30 \%$ soy flour $\left(\mathrm{S}_{2} \mathrm{~F}\right), 85 \%$ corn flour and $15 \%$ lupine flour $\left(\mathrm{L}_{1} \mathrm{~F}\right)$, $70 \%$ corn flour and $30 \%$ lupine flour $\left(\mathrm{L}_{2} \mathrm{~F}\right)$.

Gluten free cakes were prepared according to (Bennion and Pamford ,1997) with some modifications which show in table (1). The control corn flour cake was prepared by whipping butter $(150 \mathrm{~g})$ and sugar $(140 \mathrm{~g})$ to a white cream with using a mixer at high speed then eggs $(115 \mathrm{~g})$, vanilla $(5 \mathrm{~g})$ and yogurt $(125 \mathrm{~g})$ were added and whipped for $5 \mathrm{~min}$, then the other ingredients, corn flour $(150 \mathrm{~g})$, corn starch $(78 \mathrm{~g})$ and baking powder $(9 \mathrm{~g})$, were added gradually on the whipped mixture and beaten for three min. using the mixer at low speed . The mixture placed in a preheated oven and baked at $180^{\circ} \mathrm{C}$ for 40 $\min$.

The treatments were carried out by substituted corn flour with chickpea flour, soy flour and lupine flour at $15 \%$ and $30 \%$ levels. The appearances of gluten free cakes are shown in figure (1) and figure (2)

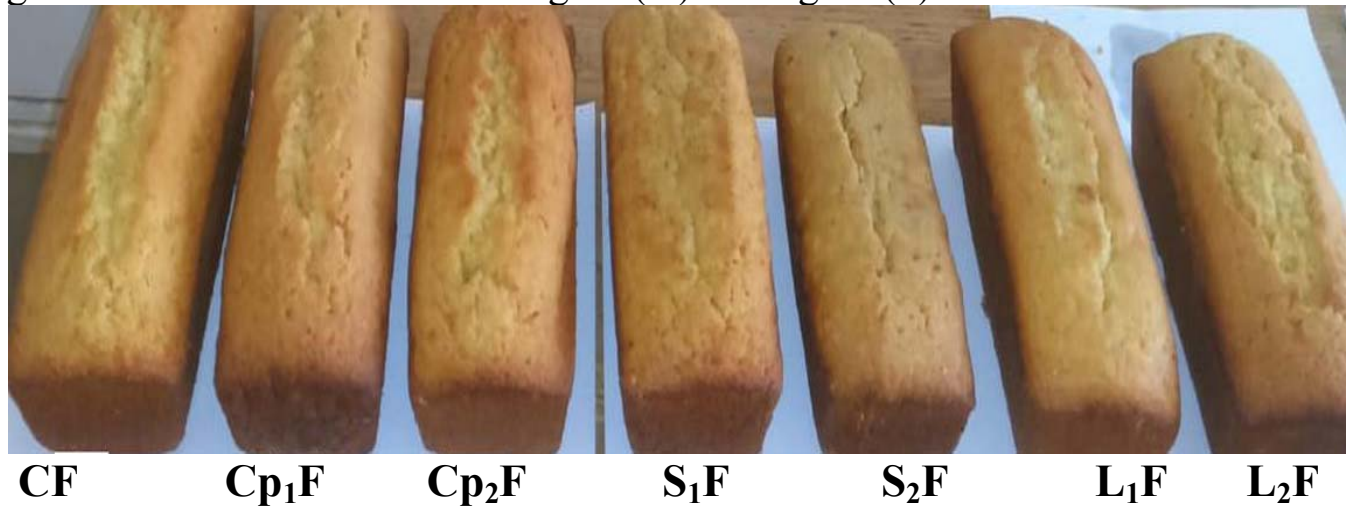

Figure (1) crust appearance of gluten free cakes 
$\mathrm{CF}: 100 \%$ corn flour (control); $\mathrm{Cp}_{1} \mathrm{~F}: 85 \%$ corn flour and 15\% chickpea flour; $\mathrm{Cp}_{2} \mathrm{~F}: 70 \%$ corn flour and 30\% chickpea flour; $\mathrm{S}_{1} \mathrm{~F}$ : $85 \%$ corn flour and 15\% soy flour; $\mathrm{S}_{2} \mathrm{~F}$ : $70 \%$ corn flour and $30 \%$ soy flour; $\mathrm{L}_{1} \mathrm{~F}: 85 \%$ corn flour and $15 \%$ lupine flour; $\mathrm{L}_{2} \mathrm{~F}: 70 \%$ corn flour and $30 \%$ lupine flour

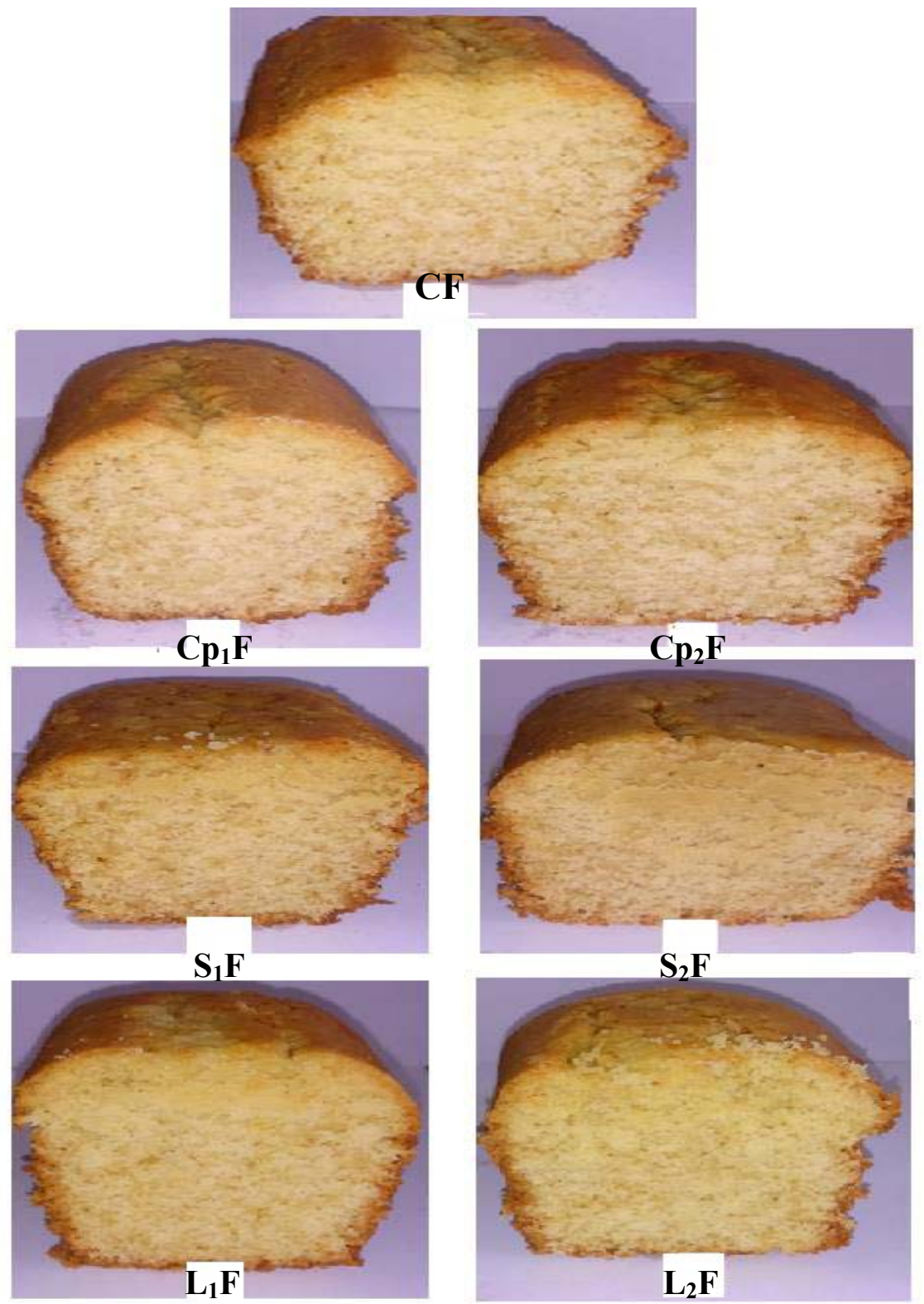

Figure (2) :crumb appearance of gluten free cakes

CF: $100 \%$ corn flour (control); $\mathrm{Cp}_{1} \mathrm{~F}: 85 \%$ corn flour and 15\% chickpea flour; $\mathrm{Cp}_{2} \mathrm{~F}: 70 \%$ corn flour and 30\% chickpea flour; $\mathrm{S}_{1} \mathrm{~F}$ : $85 \%$ corn flour and 15\% soy flour; $\mathrm{S}_{2} \mathrm{~F}$ : $70 \%$ corn flour and $30 \%$ soy flour; $\mathrm{L}_{1} \mathrm{~F}: 85 \%$ corn flour and $15 \%$ lupine flour; $\mathrm{L}_{2} \mathrm{~F}: 70 \%$ corn flour and $30 \%$ lupine flour. 


\section{Table (1): Formula of gluten free cakes}

\begin{tabular}{|c|c|c|c|c|c|c|c|}
\hline Ingredients(gm) & $\begin{array}{c}\mathbf{C F} \\
\text { cake }\end{array}$ & $\begin{array}{c}\mathbf{C p}_{\mathbf{1}} \mathbf{F} \\
\text { cake }\end{array}$ & $\begin{array}{c}\mathbf{C p}_{2} \mathbf{F} \\
\text { cake }\end{array}$ & $\begin{array}{c}\mathbf{S}_{\mathbf{1}} \mathbf{F} \\
\text { cake }\end{array}$ & $\begin{array}{c}\mathbf{S}_{2} \mathbf{F} \\
\text { cake }\end{array}$ & $\begin{array}{c}\mathbf{L}_{1} \mathbf{F} \\
\text { cake }\end{array}$ & $\begin{array}{c}\mathbf{L}_{2} \mathbf{F} \\
\text { cake }\end{array}$ \\
\hline Corn flour & 150 & 127.5 & 105 & 127.5 & 105 & 127.5 & 105 \\
\hline Corn starch & 78 & 78 & 78 & 78 & 78 & 78 & 78 \\
\hline Sugar & 140 & 140 & 140 & 140 & 140 & 140 & 140 \\
\hline Butter & 150 & 150 & 150 & 150 & 150 & 150 & 150 \\
\hline Eggs & 115 & 115 & 115 & 115 & 115 & 115 & 115 \\
\hline Vanilla & 5 & 5 & 5 & 5 & 5 & 5 & 5 \\
\hline Baking powder & 9 & 9 & 9 & 9 & 9 & 9 & 9 \\
\hline Yogurt & 125 & 125 & 125 & 125 & 125 & 125 & 125 \\
\hline Chickpea flour & - & 22.5 & 45 & - & - & - & - \\
\hline Soy flour & - & - & - & 22.5 & 45 & - & - \\
\hline Lupine flour & - & - & - & - & - & 22.5 & 45 \\
\hline
\end{tabular}

CF: $100 \%$ corn flour (control); $\mathrm{Cp}_{1} \mathrm{~F}: 85 \%$ corn flour and $15 \%$ chickpea flour; $\mathrm{Cp}_{2} \mathrm{~F}: 70 \%$ corn flour and $30 \%$ chickpea flour; $\mathrm{S}_{1} \mathrm{~F}: 85 \%$ corn flour and $15 \%$ soy flour; $\mathrm{S}_{2} \mathrm{~F}: 70 \%$ corn flour and $30 \%$ soy flour; $\mathrm{L}_{1} \mathrm{~F}$ : $85 \%$ corn flour and $15 \%$ lupine flour; $\mathrm{L}_{2} \mathrm{~F}: 70 \%$ corn flour and $30 \%$ lupine flour

\section{Chemical analysis}

Proximate analysis involving moisture, protein, fat, ash and crude fiber were carried out according to the methods of AOAC (2005) .Carbohydrates content was calculated by difference.

\section{Specific Gravity of Batter and Measurements of Cakes (physical properties)}

Specific gravity of cake batter was evaluated according to the method of (Jyotsna et al., 2004) .Weight ( $\mathrm{g})$, volume $\left(\mathrm{cm}^{3}\right)$ and specific volume $\left(\mathrm{cm}^{3} / \mathrm{g}\right)$ of different cake samples were measured according to the method of (Bennion and Bamford ,1997).

\section{Texture profile analysis of gluten free cakes}

Samples hardness, resilience, springiness, cohesiveness, gumminess and chewiness was carried out in National Research Center . Dokki, Giza ,Egypt using the TVT Texture Analyzer (Perten instruments) according to TVT Method 10.0. The analyzer was set to carried out two cycle measurements which are used for the determination of the first bite force of a product. The measurement speed of $2 \mathrm{~mm} / \mathrm{s}$ and a distance of $5 \mathrm{~mm}$ were applied. A forcetime diagram was taken for each test. The force-time plots were analyzed for peak breaking force $(\mathrm{g})$ and time (s) to reach the peak. Textural elements were 
measured in three independent samples and the presented values are mean values (Pongsawatmanit et al., 2007).

\section{Color determination method}

The color was measured by using a Hunter Lab. Model D25 color and color difference Meter (Francis, 1983). This color assessment system is based

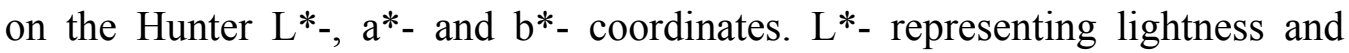
darkness, $+a^{*}$ - redness, - $a^{*}$ - greenness, $+b^{*}$ - yellowness and - $b^{*}$ - blueness with white Tile of Hunter Lab color standard: $(L=92.56, a=-0.87$ and $b=-$ $0.15)$.

\section{Organoleptic characteristics of gluten free cakes}

Organoleptic characteristics were determined according to (Levent and Bilgic, 2011) with some modification to evaluate sensory characteristics such as taste (20), odor (20), crumb color (10), crust color (10), texture (10), pore structure (10) and overall acceptability (20) of gluten free cake samples.

\section{Statistical analysis}

The current results were analyzed statistically using SPSS statistical package (Version 9.05) according to (Rattanathanalerk et al., 2005) analysis of variance (ANOVA), Duncan's multiple range test and least significant difference (LSD) was chosen to determine the significant difference among various treatments. Differences considered significant at $p \leq 0.05$.

\section{Results and Discussion}

\section{Chemical composition of gluten free cake flour blends}

Chemical composition of gluten free cake flour blends is given in table (2). Data in table (2) demonstrated that the ash content of corn flour CF was lower than the other samples recorded $(0.60 \pm 0.05 \%)$, whereas $\mathrm{S}_{2} \mathrm{~F}$ blend had the highest ash content $(1.40 \pm 0.06 \%)$. Beside this the soy flour had the highest protein content and the blend $\mathrm{S}_{2} \mathrm{~F}$ recorded $(15.97 \pm 0.50 \%)$ while corn flour had the lowest protein content of $(6.95 \pm 0.10 \%)$. In this respect, the increase in protein level could be due to the soy fraction of the blended flour because the soy flour has higher protein about $(40.2 \%)$. Soy bean is an important source of protein and complement to lysine-limited cereal protein. 
Adding of soy flour improve the quantity and quality of protein content of the food product, thereby has the great possibility in combating with protein energy malnutrition Wadsworth (1992).

The lipid content of the samples ranged from $1.85 \pm 0.04$ to $5.05 \pm 0.10 \%$. It was observed that the blend $\mathrm{S}_{2} \mathrm{~F}$ recorded the highest value of lipid. On the other hand, the highest fiber value was for $\mathrm{L}_{2} \mathrm{~F}$ blend $(3.58 \pm 0.06 \%)$ but the lowest fiber content was for CF blend $(0.50 \pm 0.01 \%)$. These results are in agreement with Zielinska et al., (2008) who stated that lupine is an important source of nutrients, like proteins, lipids, dietary fiber.

Finally, the carbohydrate content of corn flour CF was higher than the other samples $(80.80 \pm 0.80 \%)$ these results are in nearly with Khorshid et al., (1996). In another study it was found that legumes nutritional profile may also counteract the shortage of nutrients commonly highlighted in commercial gluten-free bakery products, supplying valuable sources of protein, dietary fiber, vitamins, , and minerals, which in turn have a positive effect on human health Foschia et al., (2017). In this concern, Islam et al., (2007) showed that adding $15 \%$ soy flour to bread blends improved bread quality, and nutritional properties of bread.

It was concluded that replacing corn flour (CF) with soy flour (SF), chickpea flour(Cp F) and lupine flour (LF) at levels 15\% and 30\% led to significant increase in ash, protein, lipid, fiber but it led to significant decrease in carbohydrate.

Table (2): Chemical composition of different flour types

\begin{tabular}{|c|c|c|c|c|c|c|}
\hline $\begin{array}{c}\text { Flour } \\
\text { blends }\end{array}$ & $\begin{array}{c}\text { Moisture } \\
\mathbf{\%}\end{array}$ & $\begin{array}{c}\text { Ash } \\
\mathbf{\%}\end{array}$ & $\begin{array}{c}\text { protein } \\
\mathbf{\%}\end{array}$ & $\begin{array}{c}\text { Lipid } \\
\mathbf{\%}\end{array}$ & $\begin{array}{c}\text { Fiber } \\
\mathbf{\%}\end{array}$ & $\begin{array}{c}\text { Carbohydrate } \\
\mathbf{\%}\end{array}$ \\
\hline $\mathbf{C F}$ & $9.30 \pm 0.10^{\mathrm{a}}$ & $0.60 \pm 0.05^{\mathrm{d}}$ & $6.95 \pm 0.10^{\mathrm{f}}$ & $1.85 \pm 0.04^{\mathrm{f}}$ & $0.50 \pm 0.01^{\mathrm{d}}$ & $80.80 \pm 0.80^{\mathrm{a}}$ \\
\hline $\mathbf{C} \mathbf{p}_{1} \mathbf{F}$ & $9.33 \pm 0.01^{\mathrm{a}}$ & $0.98 \pm 0.02^{\mathrm{b}}$ & $9.45 \pm 0.15^{\mathrm{e}}$ & $2.30 \pm 0.08^{\mathrm{e}}$ & $1.29 \pm 0.03^{\mathrm{c}}$ & $76.65 \pm 0.05^{\mathrm{b}}$ \\
\hline $\mathbf{C p}_{2} \mathbf{F}$ & $9.33 \pm 0.03^{\mathrm{a}}$ & $1.35 \pm 0.10^{\mathrm{a}}$ & $11.96 \pm 0.30^{\mathrm{c}}$ & $2.77 \pm 0.07^{\mathrm{d}}$ & $2.08 \pm 0.03^{\mathrm{b}}$ & $72.51 \pm 0.01^{\mathrm{d}}$ \\
\hline $\mathbf{S}_{\mathbf{1}} \mathbf{F}$ & $9.16 \pm 0.02^{\mathrm{b}}$ & $1.00 \pm 0.10^{\mathrm{b}}$ & $11.46 \pm 0.30^{\mathrm{cd}}$ & $3.45 \pm 0.07^{\mathrm{c}}$ & $1.30 \pm 0.03^{\mathrm{c}}$ & $73.63 \pm 0.80^{\mathrm{c}}$ \\
\hline $\mathbf{S}_{2} \mathbf{F}$ & $9.03 \pm 0.03^{\mathrm{c}}$ & $1.40 \pm 0.06^{\mathrm{a}}$ & $15.97 \pm 0.50^{\mathrm{a}}$ & $5.05 \pm 0.10^{\mathrm{a}}$ & $2.09 \pm 0.05^{\mathrm{b}}$ & $66.46 \pm 0.70^{\mathrm{f}}$ \\
\hline $\mathbf{L}_{\mathbf{1}} \mathbf{F}$ & $9.18 \pm 0.03^{\mathrm{b}}$ & $0.78 \pm 0.03^{\mathrm{c}}$ & $10.91 \pm 0.50^{\mathrm{d}}$ & $2.90 \pm 0.02^{\mathrm{d}}$ & $2.04 \pm 0.02^{\mathrm{b}}$ & $74.19 \pm 0.09^{\mathrm{c}}$ \\
\hline $\mathbf{L}_{2} \mathbf{F}$ & $9.04 \pm 0.01^{\mathrm{c}}$ & $0.97 \pm 0.03^{\mathrm{b}}$ & $14.86 \pm 0.40^{\mathrm{b}}$ & $3.96 \pm 0.06^{\mathrm{b}}$ & $3.58 \pm 0.06^{\mathrm{a}}$ & $67.59 \pm 0.08^{\mathrm{e}}$ \\
\hline
\end{tabular}

Different superscript letters in the same column indicate a significant $(\mathrm{p} \leq 0.05)$ difference according to Duncan's test; $\mathrm{CF}$ : $100 \%$ corn flour (control); $\mathrm{Cp}_{1} \mathrm{~F}: 85 \%$ corn flour and $15 \%$ chickpea flour; $\mathrm{Cp}_{2} \mathrm{~F}$ : $70 \%$ corn flour and $30 \%$ chickpea flour; $\mathrm{S}_{1} \mathrm{~F}$ : $85 \%$ corn flour and $15 \%$ soy flour; $\mathrm{S}_{2} \mathrm{~F}$ : $70 \%$ corn flour and $30 \%$ soy flour; $\mathrm{L}_{1} \mathrm{~F}: 85 \%$ corn flour and $15 \%$ lupine flour; $\mathrm{L}_{2} \mathrm{~F}: 70 \%$ corn flour and $30 \%$ lupine flour

\section{Physical properties of gluten free cakes}

The physical properties of gluten free cakes prepared from different flour blends are shown in table (3). These results indicated that, the highest value of cake weight $(316.50 \pm 0.50 \mathrm{~g})$ was observed by the sample $\mathrm{S}_{1} \mathrm{~F}$ cake with no significant differences with the cake samples produced from $\mathrm{CF}$ and $\mathrm{L}_{2} \mathrm{~F}$ cake $313.00+0.20 \mathrm{~g}$ and $305.00 \pm 0.30 \mathrm{~g}$ respectively on contrary to the 
lowest value of weight which investigated by the sample $\mathrm{Cp}_{1} \mathrm{~F}(286 \pm 0.30 \mathrm{~g})$ with significant differences with all cake samples except $\mathrm{Cp}_{2} \mathrm{~F}$ cake sample . Concerning the volume of cake samples the control sample $\mathrm{CF}$ recorded the highest value of volume $\left(644.73 \pm 0.40 \mathrm{~cm}^{3}\right)$ with significant differences with all samples followed by the cake sample which produced from $\mathrm{L}_{2} \mathrm{~F}(555.71 \pm 0.01$ $\mathrm{cm}^{3}$ ) however, no significant differences was observed between the sample of $\mathrm{L}_{2} \mathrm{~F}, \mathrm{Cp}_{1} \mathrm{~F}$ and $\mathrm{Cp}_{2} \mathrm{~F}$ in terms of the volume while, the lowest value of cake volume $\left(455.25 \pm 0.05 \mathrm{~cm}^{3}\right)$ which was obtained by the cake sample produced from $\mathrm{S}_{2} \mathrm{~F}$. Gomez et al., (2008) reported that with increase the level of chickpea flour, decrease in batter density which was noticed due to the less incorporation of air. It was also expected that lower batter density would lead to higher cake volume. Consequently, the results of specific volume of cake samples were observed as follow: the control sample CF recorded the highest value of specific volume $\left(2.06 \pm 0.20 \mathrm{~cm}^{3} / \mathrm{g}\right)$ with significant difference with other samples. whilst, no significant difference was found between $\mathrm{Cp}_{1}$ Fcake , $\mathrm{Cp}_{2}$ Fcake and $\mathrm{L}_{2} \mathrm{~F}$ cake $1.90 \pm 0.70,1.86 \pm 0.20$ and $1.82 \pm 0.30 \mathrm{~cm}^{3} / \mathrm{g}$ respectively concerning the specific volume. In this respect, using chickpea flour resulted in high specific volume and softness Miñarro et al., (2012).

Moreover ,Bárcenas and Rosell (2005) reported that the specific volume is increased by several factors such as the amount of protein content, fermentation condition, and using additives .Therefore, Gomez et al., (2007) attributed the high specific volumes to the clear increase in batter viscosity. They declared that the high batter viscosity slows down the rate of $\mathrm{CO}_{2}$ diffusion and consequently, allowed for improved retention through the early stage of baking.

Table (3) Physical properties of gluten free cakes

\begin{tabular}{|c|c|c|c|}
\hline Cake Samples & $\begin{array}{l}\text { Weight } \\
\text { (g) }\end{array}$ & $\begin{array}{c}\text { Volume } \\
\left(\mathrm{cm}^{3}\right)\end{array}$ & $\begin{array}{l}\text { Specific volume } \\
\qquad\left(\mathrm{cm}^{3} / \mathrm{g}\right)\end{array}$ \\
\hline CF & $313.00 \pm 0.20^{\mathrm{ab}}$ & $644.73 \pm 0.40^{\mathrm{a}}$ & $2.06 \pm 0.20^{\mathrm{a}}$ \\
\hline $\mathrm{Cp}_{1} \mathrm{~F}$ & $286.00 \pm 0.30^{\mathrm{d}}$ & $542.50 \pm 0.50^{b}$ & $1.90 \pm 0.70^{\mathrm{b}}$ \\
\hline $\mathbf{C p} \mathbf{p}_{2} \mathbf{F}$ & $296.00 \pm 0.50^{\mathrm{d}}$ & $551.25 \pm 0.80^{b}$ & $1.86 \pm 0.20^{\mathrm{b}}$ \\
\hline$S_{1} F$ & $316.50 \pm 0.50^{\mathrm{a}}$ & $515.11 \pm 0.90^{\mathrm{c}}$ & $1.63 \pm 0.10^{\mathrm{cd}}$ \\
\hline $\mathbf{S}_{\mathbf{2}} \mathbf{F}$ & $300.50 \pm 0.20^{\mathrm{bc}}$ & $455.25 \pm 0.05^{\mathrm{d}}$ & $1.51 \pm 0.20^{\mathrm{d}}$ \\
\hline $\mathbf{L}_{1} \mathbf{F}$ & $302.50 \pm 0.40^{\mathrm{bc}}$ & $511.20 \pm 0.20^{\mathrm{c}}$ & $1.69 \pm 0.10^{\mathrm{c}}$ \\
\hline $\mathbf{L}_{2} \mathbf{F}$ & $305.00 \pm 0.30^{\mathrm{ac}}$ & $555.71 \pm 0.01^{\mathrm{b}}$ & $1.82 \pm 0.30^{\mathrm{b}}$ \\
\hline
\end{tabular}

Different superscript letters in the same column indicate a significant $(\mathrm{p} \leq 0.05)$ difference according to Duncan's test; $\mathrm{CF}$ : $100 \%$ corn flour (control); $\mathrm{Cp}_{1} \mathrm{~F}: 85 \%$ corn flour and $15 \%$ chickpea flour; $\mathrm{Cp}_{2} \mathrm{~F}$ : $70 \%$ corn flour and $30 \%$ chickpea flour; $\mathrm{S}_{1} \mathrm{~F}$ : $85 \%$ corn flour and $15 \%$ soy flour; $\mathrm{S}_{2} \mathrm{~F}$ : $70 \%$ corn flour and $30 \%$ soy flour; $\mathrm{L}_{1} \mathrm{~F}: 85 \%$ corn flour and $15 \%$ lupine flour; $\mathrm{L}_{2} \mathrm{~F}: 70 \%$ corn flour and $30 \%$ lupine flour 


\section{Color measurements of gluten free cakes}

Data in table (4) demonstrated the Color measurement of gluten free cakes. Results in table (4) showed the color measurement values $\left(\mathrm{L}^{*}, \mathrm{a}^{*}\right.$ and $\left.b^{*}\right)$ of crust and crumb for gluten free cake samples. From the results presented in the same table it could be noticed that, the highest values of crust lightness ( $\mathrm{L}^{*}$ values) were recorded by $\mathrm{L}_{2} \mathrm{~F}, \mathrm{Cp}{ }_{1} \mathrm{~F}$ and $\mathrm{CF}$ cake samples $61.48 \pm 0.50$, $60.34 \pm 0.50$ and $60.08 \pm 0.50$ respectively with no significant difference between them, also, no significant difference between $\mathrm{S}_{1} \mathrm{~F}, \mathrm{~S}_{2} \mathrm{~F}$ and $\mathrm{L}_{1} \mathrm{~F}$ cakes in terms of crust ( $\mathrm{L}^{*}$ values) $53.35+0.40,56.46 \pm 0.70$ and $54.60 \pm 0.60$ respectively. While the lowest values of crust lightness $50.31 \pm 0.60$ and $53.35 \pm 0.40$ were recorded by $\mathrm{Cp}_{2} \mathrm{~F}$ and $\mathrm{S} 1 \mathrm{~F}$ respectively. Concerning the redness ( $\mathrm{a}^{*}$ ) of crust color the cake samples $\mathrm{L}_{1} \mathrm{~F}$ and $\mathrm{Cp}_{2} \mathrm{~F}$ recorded the highest values $18.63 \pm 0.30$ and $18.06 \pm 0.30$ respectively with contrast to the cake sample $S_{2}$ Fwhich recorded the lowest value of redness $10.52 \pm 0.30$ with significant differences with other samples whereas, no significant differences between the cake samples $\mathrm{Cp}_{1} \mathrm{~F}$, $\mathrm{S}_{1} \mathrm{~F}$ and $\mathrm{L}_{2} \mathrm{~F}$ in terms of redness ( $\mathrm{a}^{*}$ values) of crust cake. As for the yellowness values of crust color ( $b^{*}$ values) the cake samples $C F$ and $\mathrm{L}_{2} \mathrm{~F}$ recorded the highest values $46.23 \pm 0.60$ and $44.86 \pm 0.06$ respectively with no significant difference, on contrary to the lowest value $34.60 \pm 0.40$ which recorded by $\mathrm{S}_{2} \mathrm{Fsample}$. While, no significant differences between $\mathrm{Cp}_{1} \mathrm{~F}$ and $\mathrm{L}_{1} \mathrm{~F}$ in terms of yellowness of crust color $43.66 \pm 0.40$ and $43.84 \pm 0.04$ respectively. Also, no significant differences between $\overline{C p}_{2}$ Fand $\mathrm{S}_{1} \mathrm{~F}$ in terms of yellowness of crust color $39.11 \pm 0.50$ and $40.47 \pm 0.30$ respectively. In this respect, Singh et al., (2003) reported that the difference in color properties may be attributed to the differences in colored pigments in the flours, which in turn relies on the biological origin of the plant Corn flour had high ( $b^{*}$ values) among the others as expected.

From the same table it was observed that the highest values of crumb lightness( $\mathrm{L}^{*}$ values ) were recorded by $\mathrm{CF}$ and $\mathrm{L}_{1} \mathrm{~F}$ cake samples which recorded $75.02 \pm 0.70$ and $73.29 \pm 0.20$ respectively with no significant difference between them, While the lowest values of crumb lightness $66.81 \pm 0.60$ and $65.76 \pm 0.80$ were recorded by $S_{1} F$ and $S_{2} F$ respectively. Such findings are in agreement with Ramy et al., (2002) who stated that darkness increased as a result of the presence of germ and bran in cakes. In this respect, darkening of products containing chickpea could be attributed to an increased in Maillard reaction happening during baking due to higher lysine content. In the Maillard reaction reducing carbohydrates react by free amino acid side chains of protein mainly lysine and resulted in amino acid-sugar reaction products polymerized protein and brown pigments Mohammad et al., (2012).As well 
as, Cheftel et al., (1989) indicated that the higher amount of lupine flour leads to a darker color. The increase in color values could be attributed to interaction of protein and sugar at baking temperatures lead to a higher degree of Maillard reaction. Hence, Gomez et al., (2008) stated that Millard reaction fails to happen in cake crumb because it does not reach above $100^{\circ} \mathrm{C}$ thus, crumb color reflects of used raw materials colors in their interactions .In this concern ,darkness increased because of the presence of germ and bran in cakes. On the other hand, adding soy flour decreased $\mathrm{L}^{*}$ value because of the flour color, and Maillard and caramelization reaction, which are affected by the reaction between amino acids and sugars and water distribution Similar results were obtained by Zhao et al., (2014). Beside this soybean is reported to be rich in lysine which produces darker shades of brown color. Browning color of bakery product such as bread, biscuit may be due to caramelization, dextrinisation of starch or maillard reaction .

Concerning the redness $\left(a^{*}\right)$ of crumb color the cake samples $\mathrm{S}_{1} \mathrm{~F}$ and $\mathrm{L}_{2} \mathrm{~F}$ recorded the highest values which recorded $7.15+0.20$ and $6.85+0.10$ respectively with no significant difference between them, while the cake sample $\mathrm{L}_{1} \mathrm{~F}$ recorded the lowest value of redness $5.21+0.10$. Over there, the reason of an increasing redness could be due to a high amount of proteins leading to increased interactions between reducing sugars and amino acids Claughton and Pearce, (1989).

Regarding the yellowness values of crumb color ( $b^{*}$ values) it was observed that the cake sample $\mathrm{L}_{2} \mathrm{~F}$ recorded the highest value $44.48 \pm 0.04$, on contrary to the lowest value $33.92 \pm 0.02$ which recorded by $\mathrm{S}_{2} \mathrm{~F}$ sample. While, no significant differences between $\mathrm{Cp}_{1} \mathrm{~F}, \mathrm{Cp}_{2} \mathrm{~F}$ and $\mathrm{L}_{1} \mathrm{~F}$ in terms of yellowness of crumb color which recorded $38.78 \pm 0.08,37.99 \pm 0.01$ and $37.38 \pm 0.10$ respectively. Also, there is no significant differences between $\mathrm{CF}$ and $\mathrm{S}_{1} \mathrm{~F}$ in terms of yellowness of crumb color they recorded $41.06 \pm 0.30$ and $40.45 \pm 0.05$ respectively. In this respect Sandhu et al., (2007) reported that higher b* value of corn flour may be give out to its higher carotenoid content.

As well as, Gadallah (2017) declared that substituted rice flour with germinated chickpea flour in gluten-free cakes demonstrated significant $(\mathrm{p} \leq$ 0.05 ) increase in redness $\left(a^{*}\right)$, yellowness $\left(b^{*}\right)$ followed by substituted levels 30 and $20 \%$ compared with other treatments, wheat and rice cake samples. These results may be due to the different pigments in germinated chickpea flour which had a positive influence on yellowness of prepared gluten-free cakes. 


\begin{tabular}{|c|c|c|c|c|c|c|}
\hline \multirow{2}{*}{ 莺 } & \multicolumn{3}{|c|}{ Crust color } & \multicolumn{3}{|c|}{ Crumb color } \\
\hline & $\mathbf{L}$ & $\mathbf{a}$ & $\mathbf{b}$ & $\mathbf{L}$ & $\mathbf{a}$ & $\mathbf{b}$ \\
\hline $\mathbf{C F}$ & $60.08 \pm 0.50^{\mathrm{a}}$ & $16.29 \pm 0.20^{\mathrm{b}}$ & $46.23 \pm 0.60^{\mathrm{a}}$ & $75.02 \pm 0.70^{\mathrm{a}}$ & $5.37 \pm 0.10^{\mathrm{d}}$ & $41.06 \pm 0.30^{\mathrm{b}}$ \\
\hline$C p_{1} F$ & $60.34 \pm 0.50^{\mathrm{a}}$ & $14.28 \pm 0.10^{\mathrm{c}}$ & $43.66 \pm 0.40^{\mathrm{b}}$ & $70.29 \pm 0.60^{\mathrm{bc}}$ & $6.19 \pm 0.10^{\mathrm{c}}$ & $38.78+0.08^{\mathrm{cd}}$ \\
\hline $\mathrm{Cp}_{2} \mathbf{F}$ & $50.31 \pm 0.60^{\mathrm{c}}$ & $18.06 \pm 0.30^{\mathrm{a}}$ & $39.11 \pm 0.50^{\mathrm{c}}$ & $70.07 \pm 0.80^{\mathrm{bc}}$ & $5.97 \pm 0.10^{\mathrm{c}}$ & $37.99 \pm 0.01^{\mathrm{d}}$ \\
\hline $\mathbf{S}_{1} \mathbf{F}$ & $53.35 \pm 0.40^{\mathrm{bc}}$ & $13.52 \pm 0.20^{\mathrm{c}}$ & $40.47 \pm 0.30^{\mathrm{c}}$ & $66.81 \pm 0.60^{\mathrm{d}}$ & $7.15 \pm 0.20^{\mathrm{a}}$ & $40.45 \pm 0.05^{\mathrm{bc}}$ \\
\hline $\mathbf{S}_{2} \mathbf{F}$ & $56.46 \pm 0.70^{\mathrm{b}}$ & $10.52 \pm 0.30^{\mathrm{d}}$ & $34.60 \pm 0.40^{\mathrm{d}}$ & $65.76 \pm 0.80^{d}$ & $6.63 \pm 0.20^{\mathrm{b}}$ & $33.92 \pm 0.02^{\mathrm{e}}$ \\
\hline $\mathbf{L}_{1} \mathbf{F}$ & $54.60 \pm 0.60^{\mathrm{b}}$ & $18.63 \pm 0.30^{\mathrm{a}}$ & $43.84 \pm 0.04^{\mathrm{b}}$ & $73.29 \pm 0.20^{\mathrm{ab}}$ & $5.21 \pm 0.10^{\mathrm{d}}$ & $37.38 \pm 0.10^{\mathrm{d}}$ \\
\hline $\mathbf{L}_{2} \mathbf{F}$ & $61.48 \pm 0.50^{\mathrm{a}}$ & $14.56 \pm 0.30^{\mathrm{c}}$ & $44.86 \pm 0.06^{\mathrm{ab}}$ & $69.63 \pm 0.03^{\mathrm{c}}$ & $6.85 \pm 0.10^{\mathrm{ab}}$ & $44.48 \pm 0.04^{\mathrm{a}}$ \\
\hline
\end{tabular}

Different superscript letters in the same column indicate a significant $(\mathrm{p} \leq 0.05)$ difference according to Duncan's test; $\mathrm{CF}$ : $100 \%$ corn flour (control); $\mathrm{Cp}_{1} \mathrm{~F}: 85 \%$ corn flour and $15 \%$ chickpea flour; $\mathrm{Cp}_{2} \mathrm{~F}$ : $70 \%$ corn flour and $30 \%$ chickpea flour; $\mathrm{S}_{1} \mathrm{~F}$ : $85 \%$ corn flour and $15 \%$ soy flour; $\mathrm{S}_{2} \mathrm{~F}$ : $70 \%$ corn flour and $30 \%$ soy flour; $\mathrm{L}_{1} \mathrm{~F}: 85 \%$ corn flour and $15 \%$ lupine flour; $\mathrm{L}_{2} \mathrm{~F}: 70 \%$ corn flour and $30 \%$ lupine flour

\section{Texture profile analysis of gluten free cakes samples (TPA)}

Results presented in table (5) revealed the texture profile analysis of gluten free cake samples. Texture profile analysis is very important technique for investigating food products. The texture profile analyzer was used for the estimation of hardness (HRD), resilience (RES), Springiness (SPR), Gumminess (GUM) and Chewiness (CHW). Hardness is the peak force measured through the first compression cycle (i.e., first bite) Bourne (2002) . From the results presented in table (5) it could be observed that, the highest value of hardness was observed by the cake sample which produced from $\mathrm{Cp}_{2} \mathrm{~F}$ cake $(36.04 \pm 0.04 \mathrm{~N})$ with significant differences with other groups with contrast to the lowest value $(21.46 \pm 0.06 \mathrm{~N})$ recorded by the cake sample which produced from $\mathrm{S}_{1} \mathrm{~F}$ cake with significant differences with other groups. This means that the cake become harder with increasing level of chickpea flour.

In this concern, chickpea addition brought a clear increase in hardness probably as a result of the thickening of the crumb walls surrounding the air cells and the strengthening of the crumb construction by the protein particles Mohammad et al.,(2012). As well as, hardness and factorability are the most main criteria for textural properties of bakery products. It was noticed that products prepared with flour containing a higher protein content resulted in a harder structure Moiraghi et al., (2011). Several researchers have shown that 
protein content in flours is an important factor in the rate of hardening and staling Pateras et al., (2007). For resilience (RES) the cake sample $\mathrm{L}_{2} \mathrm{~F}$ recorded the highest value $(0.22 \pm 0.07)$, on contrary to the lowest value $(0.11 \pm 0.01)$ which recorded by $\mathrm{S}_{2} \mathrm{~F}$ sample cake. In addition that , Cohesiveness quantifies the internal resistance of food structure Ronda et al.,(2009)Cohesiveness determined from the area of work through second compression divided by the area of work during the first compression Chaiya and pongsawatmanit (2011). According to the results in the same table cohesiveness of the cake sample $\mathrm{Cp}_{2} \mathrm{~F}$ recorded the highest values $(0.43 \pm 0.03)$ with no significant differences with the cake sample $\mathrm{L}_{2} \mathrm{~F}(0.41 \pm 0.02)$ with contrast to the cake sample CF $(0.27 \pm 0.07)$ which recorded the lowest value of cohesiveness.

Springiness was defined as the distance to which the sample get better in height through the time that elapsed between the end of the first compression cycle and the start of the second pressure cycle. According springiness the cake sample $\mathrm{Cp}_{2} \mathrm{~F}$ recorded the highest value (7.29+0.09) with significant differences with other cake samples groups, on contrary to the lowest value $(6.03 \pm 0.03)$ which recorded by CF sample cake with significant differences with other cake samples groups . Gumminess was calculated by multiplying hardness and cohesiveness, therefore, chewiness was acquired from the product of hardness, cohesiveness and springiness . For Gumminess values the cake sample $\mathrm{Cp}_{2} \mathrm{~F}$ recorded the highest value $(15.53 \pm 0.03)$ with significant differences with other cake samples groups, on contrary to the lowest value $(6.30 \pm 0.20)$ which recorded by $\mathrm{CF}$ sample cake with significant differences with other cake samples groups. Chaiya and Pongsawatmanit (2011) reported that chewiness was gained from the product of hardness, cohesiveness and springiness.

These results are in agreement with obtained by Mohammad et al., (2012) who stated that chickpea addition brought a noticeable increase in crumb hardness probably as a result of the thickening of the crumb walls framing the air cells and the strengthening of the crumb structure by the protein particles .

Therefore, chewiness defined as the energy is demand to masticate solid food to a state of readiness for swallowing Karaoglu and Kotancilar(2009). Whilst ,chewiness of the cake sample $\mathrm{Cp}_{2} \mathrm{~F}$ recorded the highest value $(113.20 \pm 0.20)$ with significant differences with other cake samples groups , on contrary to the lowest value $(38.00 \pm 0.01)$ which recorded by CF sample cake with significant differences with other cake samples groups . As well as, Ronda et al.,(2009) reported that cohesiveness quantifies the internal resistance of food structure.

Gumminess was calculated by the product of that is by multiplying hardness and cohesiveness, thus chewiness, defined as the energy required to 
run down solid food to a state of readiness for swallowing was obtained from the product of hardness, cohesiveness and springiness Karaoglu and Kotancilar (2009) .In this concern, using additional ingredient like corn starch decreased crumb firmness, chewiness and increased cohesiveness, springiness, resilience Onyango et al.,( 2011).

The results of texture profile concluded that the highest values of hardness, cohesiveness, springiness, gumminess and chewiness was observed by the cake sample which produced from $\mathrm{CP}_{2} \mathrm{~F}$ cake. This means that the cake become more harder, more cohesiveness, more springiness ,more gumminess and more chewiness by increasing chickpea flour.

\section{Table ( 5) :Texture profile analysis of cake samples}

\begin{tabular}{|c|c|c|c|c|c|c|}
\hline \multirow{2}{*}{$\begin{array}{c}\text { Cake } \\
\text { samples }\end{array}$} & \multicolumn{7}{|c|}{$\begin{array}{c}\text { TPA Parameters } \\
(\mathbf{N})\end{array}$} & Resilience & Cohesiveness & $\begin{array}{c}\text { Springiness } \\
(\mathbf{m m})\end{array}$ & $\begin{array}{c}\text { Gumminess } \\
(\mathbf{N})\end{array}$ & $\begin{array}{c}\text { Chewiness } \\
(\mathbf{m J})\end{array}$ \\
\hline $\mathbf{C F}$ & $23.11 \pm 0.01^{\mathrm{f}}$ & $0.14 \pm 0.02^{\mathrm{b}}$ & $0.27 \pm 0.07^{\mathrm{g}}$ & $6.03 \pm 0.03^{\mathrm{f}}$ & $6.30 \pm 0.20^{\mathrm{g}}$ & $38.00 \pm 0.01^{\mathrm{f}}$ \\
\hline $\mathbf{C p}_{\mathbf{1}} \mathbf{F}$ & $29.88 \pm 0.04^{\mathrm{c}}$ & $0.16 \pm 0.01^{\mathrm{ab}}$ & $0.36 \pm 0.03^{\mathrm{bde}}$ & $6.98 \pm 0.01^{\mathrm{bc}}$ & $10.69 \pm 0.04^{\mathrm{b}}$ & $74.60 \pm 0.20^{\mathrm{b}}$ \\
\hline $\mathbf{C}_{\mathbf{p}} \mathbf{F}$ & $36.04 \pm 0.04^{\mathrm{a}}$ & $0.17 \pm 0.03^{\mathrm{ab}}$ & $0.43 \pm 0.03^{\mathrm{a}}$ & $7.29 \pm 0.09^{\mathrm{a}}$ & $15.53 \pm 0.03^{\mathrm{a}}$ & $113.20 \pm 0.20^{\mathrm{a}}$ \\
\hline $\mathbf{S}_{\mathbf{1}} \mathbf{F}$ & $21.46 \pm 0.06^{\mathrm{g}}$ & $0.14 \pm 0.04^{\mathrm{b}}$ & $0.37 \pm 0.02^{\mathrm{bc}}$ & $6.90 \pm 0.20^{\mathrm{c}}$ & $8.01 \pm 0.01^{\mathrm{f}}$ & $55.30 \pm 0.20^{\mathrm{e}}$ \\
\hline $\mathbf{S}_{\mathbf{2}} \mathbf{F}$ & $32.02 \pm 0.02^{\mathrm{b}}$ & $0.11 \pm 0.01^{\mathrm{b}}$ & $0.31 \pm 0.01^{\mathrm{eg}}$ & $7.13 \pm 0.03^{\mathrm{b}}$ & $9.94 \pm 0.04^{\mathrm{d}}$ & $70.90 \pm 0.02^{\mathrm{c}}$ \\
\hline $\mathbf{L}_{\mathbf{1}} \mathbf{F}$ & $24.04 \pm 0.02^{\mathrm{e}}$ & $0.16 \pm 0.06^{\mathrm{ab}}$ & $0.36 \pm 0.02^{\mathrm{bef}}$ & $6.43 \pm 0.03^{\mathrm{d}}$ & $8.73 \pm 0.01^{\mathrm{e}}$ & $55.20 \pm 0.20^{\mathrm{e}}$ \\
\hline $\mathbf{L}_{\mathbf{2}} \mathbf{F}$ & $24.50 \pm 0.50^{\mathrm{d}}$ & $0.22 \pm 0.07^{\mathrm{a}}$ & $0.41 \pm 0.02^{\mathrm{acdf}}$ & $6.23 \pm 0.03^{\mathrm{e}}$ & $10.12 \pm 0.02^{\mathrm{c}}$ & $63.10 \pm 0.10^{\mathrm{d}}$ \\
\hline
\end{tabular}

Different superscript letters in the same column indicate a significant $(\mathrm{p} \leq 0.05)$ difference according to Duncan's test; $\mathrm{CF}$ : $100 \%$ corn flour (control); $\mathrm{Cp}_{1} \mathrm{~F}: 85 \%$ corn flour and $15 \%$ chickpea flour; $\mathrm{Cp}_{2} \mathrm{~F}$ : $70 \%$ corn flour and 30\% chickpea flour; $\mathrm{S}_{1} \mathrm{~F}$ : $85 \%$ corn flour and $15 \%$ soy flour; $\mathrm{S}_{2} \mathrm{~F}$ : $70 \%$ corn flour and $30 \%$ soy flour; $\mathrm{L}_{1} \mathrm{~F}: 85 \%$ corn flour and $15 \%$ lupine flour; $\mathrm{L}_{2} \mathrm{~F}: 70 \%$ corn flour and $30 \%$ lupine flour

\section{Organoleptic characteristics of gluten free cakes}

Data in table (6) demonstrated the organoleptic characteristics of gluten free cakes .Sensory analysis is carried out by using experienced panelists to measure sensory characteristics like taste, odor, crumb color, crust color, texture, Pore structure and overall acceptability.

From table( 6) it was observed that control gluten free cake (CF) was classified significantly with the highest scores for taste, odor, crumb color, crust color ,texture, Pore structure and overall acceptability.

Taste is the most main factor which affects the acceptability of an edible product Farzana and Mohajan (2015). The best taste was for (CF) cake and 
the lowest taste was for L2F cake. These evaluation attributes decreased with the addition of soy flour, chickpea flour and lupine flour at different levels $15 \%$ and $30 \%$.In addition that, the lowest evaluation of odor and crumb color was obtained for $\mathrm{L}_{2} \mathrm{~F}$ cake. It was found that there is no significant differences between control gluten free cake $\mathrm{CF}, \mathrm{Cp}_{1} \mathrm{~F}$ and $\mathrm{Cp}_{2} \mathrm{~F}$ cakes in taste, odor, crumb color, crust color these results are in harmonization with Gadallah (2017) who stated that using germinated chickpea flour at $20 \%$ as substitution levels of rice flour produced good gluten-free cakes with acceptable freshness and sensory properties for celiac people . Regarding texture, there is no statistical difference with control gluten-free cake(CF) and cake with $15 \%$ chickpea flour $\mathrm{Cp}_{1} \mathrm{~F}$ cake .Concerning Pore structure the lowest score for sensory attributes were obtained for cake with $30 \%$ soy bean $\mathrm{S}_{2} \mathrm{~F}(5.28 \pm 0.01)$ , while the highest score for Pore structure were obtained for CF cake $(8.64 \pm 0.02)$.Results of overall acceptability showed that the highest value was found for $\mathrm{CF}$ cake $(16.68 \pm 0.01)$ and $\mathrm{Cp}_{1} \mathrm{~F}$ cake(16.06 \pm 0.01$)$, whereas the lowest value of overall acceptability was found for $\mathrm{S}_{2} \mathrm{~F}$ cake $(12.64 \pm 0.02)$. Beside this, another studies have found that soy could improve the crumb, volume, and absorption properties of the bakery products Sanchez et al., (2004).

In this respect Miñarro et al., (2012) stated that using soy flour gave good sensory appearance. Therefore, Farzana and Mohajan, (2015) declared that adding $10 \%$ or $15 \%$ soy flour to other flours gave acceptable products. whereas, other studies declared that incorporation of soy flour more than $15 \%$ did not produce acceptable products. Furthermore, Bunde et al., (2010) reported that nutritional and functional characteristics of soy flour efficiently used to prepare bakery products like bread, muffins, etc .

On the other hand, Levent and Bilgiçli (2011) revealed that gluten-free cake could be produced with satisfactory results by adding lupine flour up to $30 \%$ respectively.

It was concluded that gluten-free cake could be produced with satisfactory results by replacing corn flour with soy flour (SF ), chickpea flour (CPF) and lupine flour (LF) at $15 \%$ and $30 \%$, respectively. In addition that , $\mathrm{Cp}_{1} \mathrm{~F}$ and $\mathrm{Cp}_{2} \mathrm{~F}$ cakes showed higher overall acceptability values after $\mathrm{CF}$ where they recorded $16.06 \pm 0.01$ and $15.60 \pm 0.03$ respectively. 
Table (6) : Organoleptic characteristics of gluten free cake samples

\begin{tabular}{|c|c|c|c|c|c|c|c|}
\hline 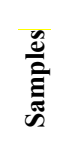 & 苟 & ఫัँ & 参 & 绨兽 & $\stackrel{\stackrel{\Xi}{e}}{\stackrel{0}{e}}$ & 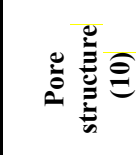 & 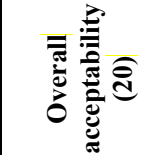 \\
\hline $\mathrm{CF}$ & $18.36+0.01^{\mathrm{a}}$ & $19.50 \pm 0.02^{\mathrm{a}}$ & $9.48+0.01^{\mathrm{a}}$ & $9.34+0.03^{\mathrm{a}}$ & $8.54+0.01^{\mathrm{a}}$ & $8.64+0.02^{\mathrm{a}}$ & $16.68+0.01^{\mathrm{a}}$ \\
\hline $\mathrm{Cp}_{1} \mathrm{~F}$ & $17.95 \pm 0.03^{\mathrm{ab}}$ & $18.64 \pm 0.01^{\mathrm{a}}$ & $9.40 \pm 0.01^{\mathrm{a}}$ & $9.12 \pm 0.01^{\mathrm{ab}}$ & $8.21 \pm 0.02^{\mathrm{a}}$ & $8.00 \pm 0.01^{\mathrm{b}}$ & $16.06 \pm 0.01^{\mathrm{ab}}$ \\
\hline $\mathrm{Cp}_{2} \mathrm{~F}$ & $17.54 \pm 0.02^{\mathrm{ab}}$ & $18.43 \pm 0.01^{\mathrm{ab}}$ & $9.00 \pm 0.03^{\mathrm{a}}$ & $9.05 \pm 0.01^{\mathrm{ab}}$ & $7.31 \pm 0.01^{b}$ & $7.01 \pm 0.03^{\mathrm{c}}$ & $15.60 \pm 0.03^{\mathrm{b}}$ \\
\hline$S_{1} \mathbf{F}$ & $17.13+0.01^{\mathrm{bc}}$ & $17.40 \pm 0.06^{\mathrm{b}}$ & $8.83+0.05^{\mathrm{ab}}$ & $8.63+0.02^{\mathrm{bc}}$ & $6.85 \pm 0.03^{\mathrm{c}}$ & $6.13 \pm 0.05^{\mathrm{d}}$ & $14.62 \pm 0.01^{c}$ \\
\hline $\mathbf{S}_{2} \mathbf{F}$ & $16.22+0.01^{\text {cd }}$ & $14.58 \pm 0.05^{\text {cd }}$ & $7.75+0.05^{\mathrm{bc}}$ & $6.98+0.02^{\mathrm{d}}$ & $5.11+0.01^{\mathrm{d}}$ & $5.28+0.01^{\mathrm{e}}$ & $12.64+0.02^{\mathrm{d}}$ \\
\hline $\mathbf{L}_{1} \mathbf{F}$ & $15.34 \pm 0.04^{d}$ & $15.64+0.03^{\mathrm{c}}$ & $7.60 \pm 0.02^{\mathrm{c}}$ & $8.25 \pm 0.05^{\mathrm{c}}$ & $7.23 \pm 0.02^{\mathrm{bc}}$ & $7.61 \pm 0.02^{\mathrm{b}}$ & $14.00 \pm 0.01^{\mathrm{c}}$ \\
\hline $\mathbf{L}_{2} \mathbf{F}$ & $14.22 \pm 0.05^{\mathrm{c}}$ & $13.84 \pm 0.01^{\mathrm{d}}$ & $7.24 \pm 0.02^{\mathrm{c}}$ & $7.46 \pm 0.06^{\mathrm{d}}$ & $7.15 \pm 0.04^{\mathrm{bc}}$ & $7.64 \pm 0.01^{b}$ & $12.90 \pm 0.01^{\mathrm{d}}$ \\
\hline
\end{tabular}

Different superscript letters in the same column indicate a significant $(\mathrm{p} \leq 0.05)$ difference according to Duncan's test; $\mathrm{CF}$ : $100 \%$ corn flour (control); $\mathrm{Cp}_{1} \mathrm{~F}: 85 \%$ corn flour and $15 \%$ chickpea flour; $\mathrm{Cp}_{2} \mathrm{~F}$ : $70 \%$ corn flour and 30\% chickpea flour; $\mathrm{S}_{1} \mathrm{~F}$ : $85 \%$ corn flour and $15 \%$ soy flour; $\mathrm{S}_{2} \mathrm{~F}$ : $70 \%$ corn flour and $30 \%$ soy flour; $\mathrm{L}_{1} \mathrm{~F}: 85 \%$ corn flour and $15 \%$ lupine flour; $\mathrm{L}_{2} \mathrm{~F}: 70 \%$ corn flour and $30 \%$ lupine flour

\section{Conclusion}

The aim of this study was to assess the effect of replacing corn flour (CF) with soy flour (SF ), chickpea flour ( $\mathrm{Cp} \mathrm{F}$ ) and lupine flour (LF) on chemical, physical, texture ,color and sensory characteristics of innovated gluten-free (GF) cakes. Regarding chemical properties, the main results concluded that replacing corn flour with soy flour, chickpea flour and lupine flour at levels $15 \%$ and $30 \%$ led to significant increase in ash, protein ,lipid, fiber but it led to significant decrease in carbohydrate. Concerning physical properties, it was found that these replacement processes decreased the values of volume and specific volume. Furthermore, the results of color measurements revealed that there is no significant differences between $\mathrm{CF}$ cake, $\mathrm{Cp}_{1} \mathrm{~F}$ cake and $\mathrm{L}_{2} \mathrm{~F}$ cake in crust $\left(\mathrm{L}^{*}\right)$ values. Over there, there is no significant differences between $\mathrm{CF}$ cake, $\mathrm{L}_{1} \mathrm{~F}$ cake in crumb $\left(\mathrm{L}^{*}\right)$ values. Concerning texture profile the highest values of hardness, Cohesiveness, Springiness, gumminess and chewiness was observed by the cake sample which produced from $\mathrm{CP}_{2} \mathrm{~F}$ cake. This means that the cake become more harder, more cohesiveness, more springiness, more gumminess and more chewiness by increasing chickpea flour. For sensory evaluation it was observed that innovative gluten-free cakes could be produced by replacing corn flour with soy flour, chickpea flour and lupine flour at level $15 \%$ and $30 \%$ respectively and CF cake was distributing significantly with the highest scores for taste, odor , crumb color, crust color ,texture, Pore structure and overall acceptability. In addition that, $\mathrm{Cp}_{1} \mathrm{~F}$ and $\mathrm{Cp}_{2} \mathrm{~F}$ cakes showed higher overall acceptability after CF cake. The study recommended that entering soy flour, chickpea flour and lupine flour in making products for celiac people. 


\section{References}

AOAC (2005): Official Methods of Analysis of Association of Official Analytical Chemists. In: Kenesseth Helrick, B., Ed., 15th Edition

Ahmad, A.; Hayat, I.; Arif, S.;Masud. T; Khalid ,N. and Ahmed, A. (2014): Mechanisms Involved in the Therapeutic Effects of Soybean (Glycine Max).International Journal of Food Properties, 17, 1332-1354.

Al-Omari, D. ( 2009) : Effect of addition of germinated lupin flour on the physiochemical and organoleptic properties of coolies. M.Sc. Thesis, Jordan University of Science and Technology, Jordan.

Arendt, E. ; Morrissey ,A. ; Moore, M. and Dal Bello ,F.( 2008) : Glutenfree cereal product and beverages. Academic Press, imprint of Elsevier,:289310.

Bárcenas, M.E and Rosell, C.M.(2005): Effect of HPMC addition on the microstructure,quality and aging of wheat bread. Food Hydrocolloid;19:10371043.

Bascujonn ,K.A; Vespa, M.C. and Araya, M. (2016) :Celiac disease: understanding the gluten-free diet. Rev Eur J Nutr., doi:10.1007/s00394-0161238-5.

Bennion, E.B. and Bamford, G.S. (1997): The Technology of Cake Making. 6th Edition, Blacking Academic and Professional, Chapman and Hall, London, 112-120, 277, 285-288.

Bourekoua ,H; Benatallah, L; Zidoune, M. and Rosell ,C (2016):Developing gluten free bakery improvers by hydrothermal treatment of rice and corn flours. LWT Food Sci. Technol ,73:342-350

Bourne, M.C. ( 2002): Food Texture and Viscosity.Concept and Measurement, $2^{\text {nd }}$ ed. Academic Press. London. 427 pp.

Bunde, M.; Osundahunsi, F. and Akinoso , R. (2010): Supplementation of biscuit using rice bran and soyabean flour.Ajfand, 10 (9):47-59.

Caio, G. ; Volta, U.; Sapone, A.; Daniel, A. ; Giorgio, R. C.; Catassi, C. and Fasano, A (2019):Celiac disease: a comprehensive current review. BMC Medicine J, 17:142.

Catassi, C.; Fasano, A.; Arendt ,E. and Dal Bello, F(2008): Gluten-free cereal products and beverages. Academic Press, imprint of Elsevier, 1-22.

Chaiya, B and Pongsawatmanit, R (2011) : Quality of batter and sponge cake prepared from wheat-tapioca flour blends. Kasetsart Journal - Natural Science, 45(2):305-313.

Cheftel, J. C.; Cuq ,J. L. and Lorient, D. (1989) : Prote' nas Alimentarias: Bioqu' 1mica, Propiedades Funcionales, Valor Nutricional, Modificaciones Qu' imicas, Acribia. 
Claughton, S.M. and Pearce, R.J. (1989): Protein enrichment of sugar-snap cookies with sunflower protein isolates. J. Food Sci., 54: 354.

Dimitrios, S.; Eleousa M. and Georgios, D. (2006): Effect of durum flour enrichment with chickpea flour on the characteristics of dough and lasagna. Journal of the Science of Food and Agriculture, 86(12), 1938-1944.

Doweidar, M. M. (2006): Production and evaluation of gluten free cake. Bull. Fac. Agric. Cairo Univ., 57: 665-684.

Faluyi, M ; Zhou, X ; Zhang, F ; Leibovitch, S; Migner, P. and Smith , D. (2000) : Seed quality of sweet white lupin (Lupinus albus) and management practice in eastern Canada. European Journal of Agronomy, 13: 7-37.

Farzana, T. and Mohajan, S. (2015): Effect of incorporation of soy flour to wheat flour on nutritional and sensory quality of biscuits fortified with mushroom. Food Science and Nutrition, 3: 363-369.

Fasano, A.; Berti, I.; Gerarduzzi ,T.; Not ,T.; Colletti ,R.; Drago, S., Elitsur ,Y.; Green ,P.; Guandalini ,S.; Hill, I. and Horvath, K. (2003): Prevalence of celiac disease in at-risk and not-at-risk groups in the United States: a large multicenter study. Archives of Internal Medicine, 163: 286-292.

Foschia, Martina; Horstmann, S; Arendt, E. and Zannini, E (2017) : Legumes as Functional Ingredients in Gluten-Free Bakery and Pasta Products. Annual Review of Food Science and Technology, 8:75-96 .

Francis, F.J. (1983): Colorimetry of Foods. In: Peleg, M. and Bagly, E.B., Eds., Physical Properties of Foods , The AVI Publishing Company Inc., Westport, CT, 105-123.

Gadallah, M.G.E (2017): Rheological,Organoleptical and Quality Characteristics of Gluten-Free Rice Cakes Formulated with Sorghum and Germinated Chickpea Flours . Food and Nutrition Sciences, 8: 535-550.

Gomez, M.; Ronda, F.; Caballero, P.; Blanco, C. and Rosell, C. (2007): Functionality of different hydrocolloids on the quality and shelf-life of yellow layer cakes. Food Hydrocolloids, 21, 167-173.

Gomez, M.; Oliete, B.; Rosell, C.; Valent, P. and Fernandez, E. (2008): Studies on cake quality made of wheat- chickpea flour blends, LWT - Food Science and Technology, 41: 1701-709.

Gularte, M.; De la Hera, E; Gómez, M. and Rosell, C. (2012): Effect of different fibers on batter and gluten-free layer cake properties. LWT Food Sci Technol. , 48:209-214.

Hill, I.; Dirks, M.; Liptak, G.; Colletti, R.; Fasano, A. and Guandalini, S (2005): Guideline for the Diagnosis and Treatment of Celiac Disease in Children: Recommendations of the North American Society for Pediatric Gastroenterology, Hepatology and Nutrition. Journal of Pediatric Gastroenterology Nutrition, 40: 1-19. 
Islam, T.; Chowdhury, A.; Islam, M., and Islam, S. (2007): Standardization of Bread Preparation from Soy Flour. International Journal of Sustainable Crop Production, 2: 15-20.

Jyotsna, R.; Prabhasankar, P;Indrani, D. and Rao, G. (2004): Improvement of Rheological and Baking Properties of Cake Batters with Emulsifier Gels. Journal of Food Science, 69: 16-19.

Karaoglu, M.M. and Kotancilar. H.G. (2009): Quality and textural behaviour of par-baked and rebaked cake during prolonged storage. Int. J. Food Sci. Tech., 44:93-99.

Khan, E.A.; Aslam, M.; Ahmad, H.K.; Himayatullah, Khan, M.A. and Hussain, A. (2010): Effect of row spacing and seeding rates on growth, yield and yield components of chickpea. Sarhad J. Agric., 26 (2): 201-211.

Khorshid, A. M.; Emam, M. S. and Mansour, S. M. (1996): Effect of preparatuion techniques of bread quality produced from whole maize kernel. $2^{\text {nd }}$ International Conf. on Food Sci. and Tecchnol. Cairo, Egypt.

Levent, H. and Bilgiçli, N. (2011): Enrichment of gluten-free cakes with lupin (Lupinus albus L.) or buckwheat (Fagopyrum esculentum M.) flours. International Journal of Food Sciences and Nutrition, 62(7): 725-728.

Mastromatteo, M.; Chillo, S.; Iannetti, M.; Civica, V. and Del Nobile, M.(2011): Formulation optimisation of gluten-free functional spaghetti based on quinoa, maize and soy flours. Int. J. Food Sci. Technol., 46: 1201-1208.

Matos, M.; Sanz ,T. and Rosell, C. (2014): Establishing the function of proteins on the rheological and quality properties of rice based gluten free muffins. Food Hydrocoll. , 35:150-158.

Miñarro ,B; Albanell ,E; Aguilar, N; Guamis ,B. and Capellas, M. (2012) : Effect of legume flours on baking characteristics of gluten-free bread. J Cereal Sci ., 56:476-81.

Moiraghi, M ; Vanzetti ,L; Bainotti ,C; Helguera ,M; Leon, A. and Perez, G. (2011): Relationship between soft wheat flour physicochemical composition and cookie-making performance. Cereal Chemistry, 88(2): 130-136.

Mohammad ,I ; Ahmed,A. and Senge ,B .(2012) : Dough rheology and bread quality of wheat-chickpea flour blends. Ind Crops Prod., 36:196-202.

Onyango, C.; Mutungi, C.; Unbehend, G. and Lindhauer, M. (2011): Modification of gluten-free sorghum batter and bread using maize, potato, cassava or rice starch. Lebensmittel-Wissenschaft Technologie, 44(3): 681686.

Osella ,C.; La Torre ,M. and Sjnchez ,H. (2014): Safe foods for celiac people. Food Nutri Sci., 5:787-800

Pateras, I.M; Cauvain ,S.P. and Young,L.S (2007): Bread spoilage and staling. Technology of bread making, New York, Springer, 275-99. 
Pongsawatmanit, R.; Temsiripong, T. and Suwonsichon, T. (2007): Thermal and rheological properties of tapioca starch and xyloglucan mixtures in the presence of sucrose. Food Res. Int., 40: 239-248.

Ramy, A. ; Salama, M. and Shouk, A. (2002): Pollards a potential source of dietary fiber for pasta manufacture. Egypt Journal of Food Science, 30: 313-330

Rattanathanalerk, M.; Naphaporn, C. and Walaiporn, S. (2005): Effect of thermal processing on the quality loss of pineapple juice. J. Food Eng., 66:259265.

Ronda, F.; Gómez, M.; Caballero, P.A; Oliete ,B. and Blanco ,C.A. (2009): Improvement of Quality of Gluten-free Layer Cakes. Food Science and Technology International; 15: 193.

Sanchez, H.; Osella, C. and De La Torre, M. (2004): Use of response surface methodology to optimize gluten-free bread fortified with soy flour and dry milk. Food Science and Technology International, 10: 5-9.

Sandhu, K.; Singh ,N. and Malhi, N. (2007): Some properties of corn grains and their flours: Physicochemical, functional and chapati-making properties of flours. Food Chemistry ,101: 938-946.

Schober, T.; Bean, S.; Boyle, D. and Park, S. (2008) : Improved viscoelastic zein-starch doughs for leavened gluten-free breads: Their rheology and microstructure. J. Cereal Sci., 48: 755-767.

Singh, J., N. ; Sharma , T.R. and Saxena, S.K. (2003): Physicochemical, rheological and cookie making properties of corn and potato flours. Food Chem., 83: 387-393.

Sollid, L. (2002):Coeliac disease: dissecting a complex inflammatory disorder. Nature Reviews Immunology , 2: 647-655.

Stone, W ; Bauer, L. and Bunning, M (2017): Gluten-Free Baking. food science and human nutrition., Fact sheet 9:376.

Wadsworth , J.I (1992): Encyclopedia of Food Science and Technology, $4^{\text {th }}$ ed. New York, Pa: John Wiley and sons, 264-279.

Zhao, Q.; Selomulya, C.; Xiong, H.; Chen, X.; Li, X.; Wang, S. and Sun, W.(2014): Rice Dreg Protein as an Alternative to Soy Protein Isolate: Comparison Comparison of Nutritional Properties. International Journal of Food Properties, 17: 1791-1804.

Zielinska, D.; Frias, J.; Piskuła, M..; Kozłowska, H.; Zielinski, H. and Vidal-Valverde, C. ( 2008): Evaluation of the antioxidant capacity of lupine sprouts germinated in the presence of selenium. Europ. Food Res. Technol., 227: $1711-1720$. 


\section{Abstract}

\section{Study the Different Properties of Innovative Cake Blends for Patients with Gluten Sensitivity}

The aim of this study was to assess the effect of soy flour (SF ), chickpea flour (Cp F) and lupine flour (LF) on chemical, physical, texture , color and sensory characteristics of innovative gluten-free cakes. In this study corn flour was replaced with soy flour, chickpea flour and lupine flour at different levels $15 \%$ and $30 \%$ to produce more nutritionally balanced glutenfree cakes. Chemical, physical, color, texture and sensory properties were measured in gluten free cake samples .Seven gluten -free cake flour blends were prepared : control: $100 \%$ corn flour (CF), 85\% corn flour and 15\% chickpea flour $\left(\mathrm{Cp}_{1} \mathrm{~F}\right), 70 \%$ corn flour and $30 \%$ chickpea flour $\left(\mathrm{Cp}_{2} \mathrm{~F}\right), 85 \%$ corn flour and $15 \%$ soy flour $\left(\mathrm{S}_{1} \mathrm{~F}\right), 70 \%$ corn flour and $30 \%$ soy flour $\left(\mathrm{S}_{2} \mathrm{~F}\right)$, $85 \%$ corn flour and $15 \%$ lupine flour $\left(\mathrm{L}_{1} \mathrm{~F}\right), 70 \%$ corn flour and $30 \%$ lupine flour $\left(\mathrm{L}_{2} \mathrm{~F}\right)$.Regarding chemical properties, the main results concluded that replacing corn flour with soy flour, chickpea flour and lupine flour at levels $15 \%$ and $30 \%$ led to significant increase $(\mathrm{P} \leq 0.05)$ in ash, protein, lipid, fiber but it led to significant decrease $(\mathrm{P} \leq 0.05)$ in carbohydrate. Concerning physical properties the highest value of cake weight $(316.50 \pm 0.50 \mathrm{~g})$ was observed by the sample $\mathrm{S}_{1} \mathrm{~F}$ cake but the lowest value of weight which investigated by the sample $\mathrm{Cp}_{1} \mathrm{~F}$ $(286.00 \pm 0.30 \mathrm{~g})$. Therefore, the control sample CF recorded the highest value of volume and specific volume with significant difference with other samples. Furthermore, the results of color measurement $\left(\mathrm{L}^{*}, \mathrm{a}^{*}\right.$ and $\left.\mathrm{b}^{*}\right)$ revealed that there is no significant differences between $\mathrm{CF}$ cake, $\mathrm{Cp}_{1} \mathrm{~F}$ cake and $\mathrm{L}_{2} \mathrm{~F}$ cake in crust $\left(\mathrm{L}^{*}\right)$ values. Over there, there is no significant differences between $\mathrm{CF}$ cake, $\mathrm{L}_{1} \mathrm{~F}$ cake in crumb $\left(\mathrm{L}^{*}\right)$ values. Whereas ,the highest value of crust $\left(\mathrm{a}^{*}\right)$ was for L1F cake which recorded $(18.63 \pm 0.30)$ and for crumb color was for S1F cake which recorded (7.15 \pm 0.20$)$.In addition that ,the highest value for crust $\left(b^{*}\right)$ was for CF cake $(46.23+0.60)$ and the highest value for crumb $\left(b^{*}\right)$ was for $\mathrm{L}_{2} \mathrm{~F}$ cake which recorded $(44.48 \pm 0.04)$. Whereas, the results also declared that the texture profile affect by replacement processes, the results of hardness, resilience, cohesiveness and chewiness ranged From 21.46 \pm 0.06 $: 36.04 \pm 0.04,0.11 \pm 0.01: 0.22 \pm 0.07,0.27 \pm 0.07: 0.43 \pm 0.03,38.00 \pm 0.01$ : $113.20 \pm 0.20$.The results of the sensory evaluation judged by panelists indicated that CF cake was distributing significantly with the highest scores for taste, odor , crumb color, crust color ,texture , Pore structure and overall acceptability. These results also revealed that there is no significant differences 
between control gluten free cake $\mathrm{CF}, \mathrm{Cp}_{1} \mathrm{~F}$ and $\mathrm{Cp}_{2} \mathrm{~F}$ cakes in taste, odor, crumb color, crust color. In addition that, $\mathrm{Cp}_{1} \mathrm{~F}$ and $\mathrm{Cp}_{2} \mathrm{~F}$ cakes showed higher overall acceptability values after $\mathrm{CF}$ where they record $16.06 \pm 0.01$ and $15.60 \pm 0.03$ respectively. It was concluded that innovative gluten-free cakes could be produced with satisfactory results by replacing corn flour with soy flour, chickpea flour and lupine flour at level $15 \%$ and $30 \%$ respectively. The study recommended entering of soy flour, chickpea flour and lupine flour in making products for celiac people.

Keywords: celiac disease, corn flour, soy flour, chickpea flour, lupine flour, chemical properties, physical properties, texture profile ,color measurements and sensory properties- gluten free cakes.

\section{ملخص البحث \\ دراسة الخصائص المختلفة لخلطات مبتكرة من الكيك تصلح لمرضي حساسية الجلوتين}

هدفت الدراسة الحالية إلي معرفة تأثثر استبدال دقيق الذرة في الكيك الخالي من الجلوتين بكل

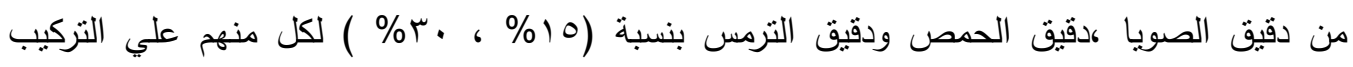
الكيميائي ، الخواص الفيزيائية ، الخواص الحسية ، خواص الملمس والخواص اللونية للكيك المنتج .

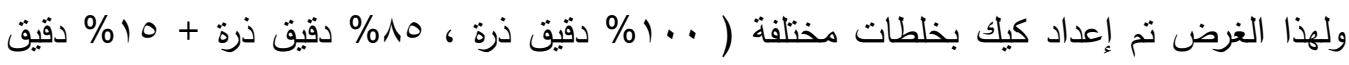

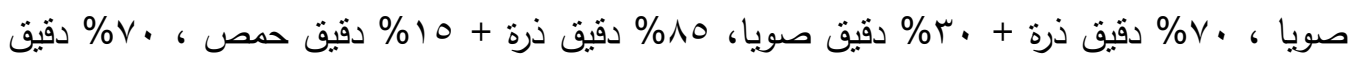

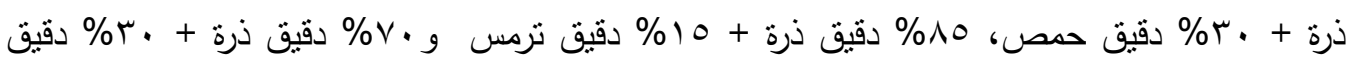
ترمس). وقد أنشارت النتائج إلي أن الاستبدال قد أدي إلي زيادة معنوية (P

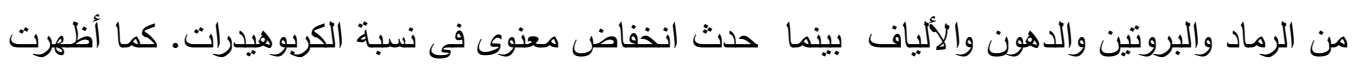

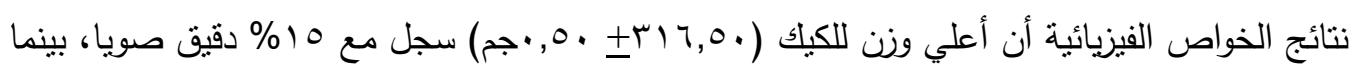

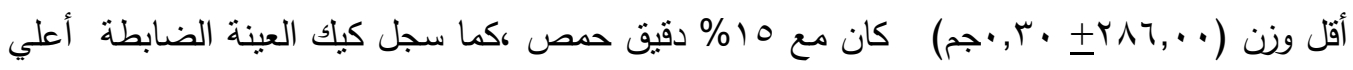
قيمة بالنسبة للحم ( 


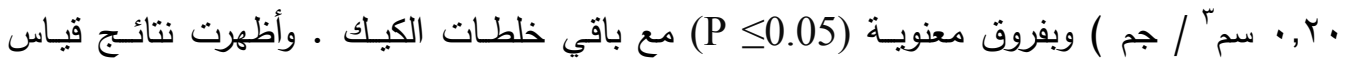

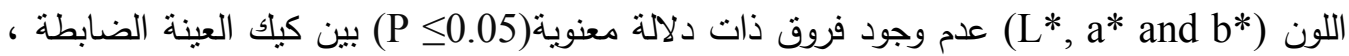

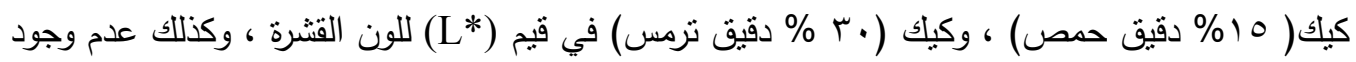

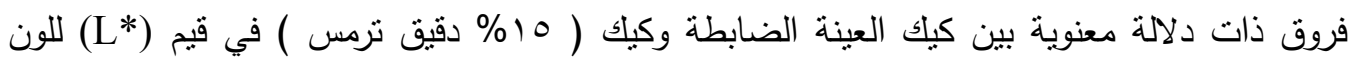

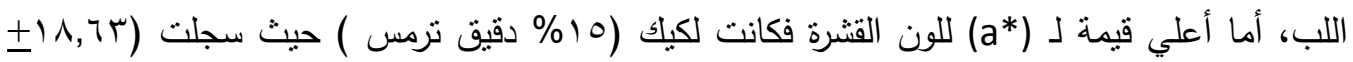

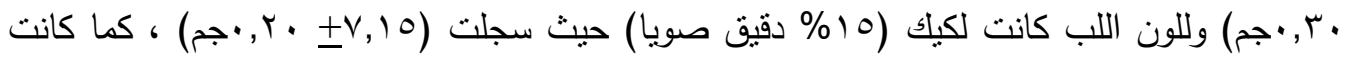

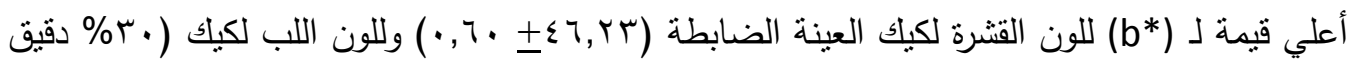

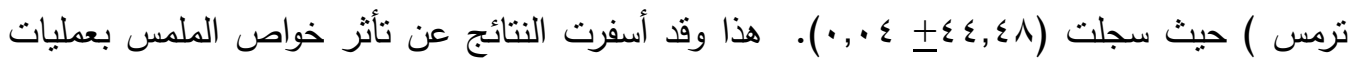

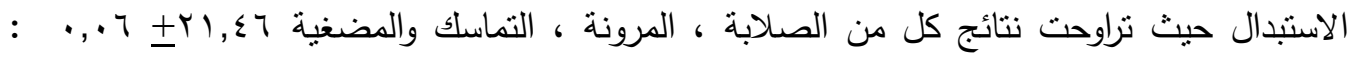

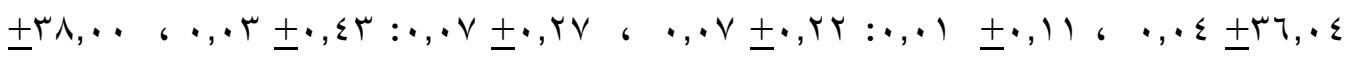

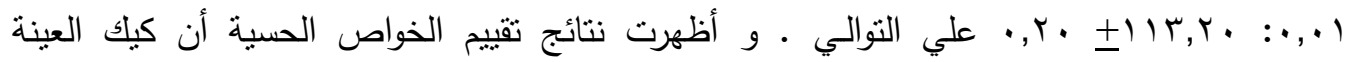

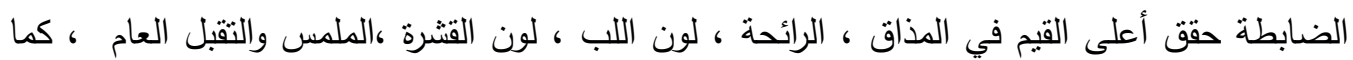

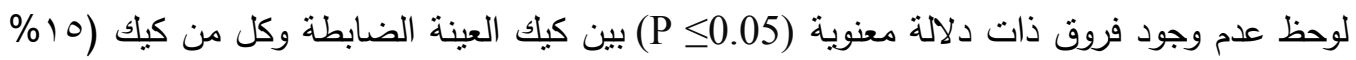
دقيق حصص ) وكيك (•r\% دقيق حصص ) في المذاق ، الرائحة ، لون اللب ولون القشرة ، كما أظهر

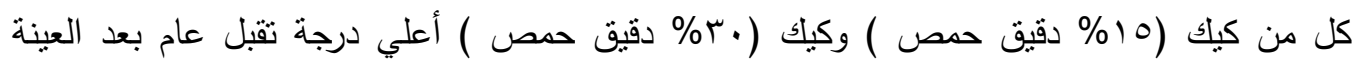

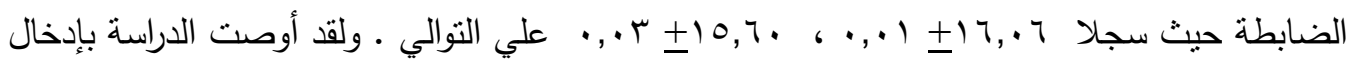
كل من دقيق الحمص ، دقيق الصويا ودقيق الترمس فى عمل منتجات تصلح لمرضى حساسية

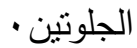

الكلمات المفتاحية: مرض حساسية الجلوتين ، دقيق الذرة ، دقيق الصويا ، دقيق الحمص ، دقيق التزمس ، التركيب الكيميائي ، الخصائص الفيزيائية ، الخواص اللونية، خواص الملمس ،الخواص الحسية، الكيك الخالي من الجلوتين. 